\title{
PERMASALAHAN SOSIAL PADA MASYARAKAT LADANG BERPINDAH AKIBAT PERKEBUNAN KELAPA SAWIT DI DESA SEMPURNA KECAMATAN SUNGAI LAUR KABUPATEN KETAPANG
}

\author{
(Social Problem In Coltivation Commuties Due The Palm Oil Plantation In The Sempurna \\ Village Sungai Laur Sub District Ketapang District)
}

\author{
Jepri yandi, Iskandar, M. Idham \\ Fakultas Kehutanan Universitas Tanjungpura. Jalan Imam Bonjol Pontianak 78124 \\ E-mail: jefriy540@gmail.com
}

\begin{abstract}
Shifting cultivation is an agricultural system, that has the characteristic of cutting or slashing techniques, which are burned in dry land areas, there is no intensive irrigation and are palnted with sort-lived plants. In general, after being worked on for less than three years, they are left behind. The plants are of rice secondary crops with a simple processing technique, namely by using tugal, accompanied by land use and palnt maintaince without fertilization According to Koentjaraningrat (1977), Almost all of the people in Sempurna village before the palm oil plantations used to do shifting cultivation, but after the oil palm plantations began operating in 2002 the peoples who carried out shifting cultivation from 428 households recorded only $2.8 \%$ or 12 families. The purpose of this study was to examine the social problems of shifting fields due to oil palm plantation in the Sempurna village, Sungai Laur sub-district, Ketapang district. The benefits of this study as information to policy makers in Ketapang district about social problem in shifting fields communities due to the oil palm plantation in the Sempurna village, Sungai Laur sub-district, Ketapang district with the survey method. Data collection techniques through observation, interviews and documentation. Interviews were conducted by purposive sampling, namely the discussion in the form data analysis which included the interpretation of all data collected, arrange the results of the research in such away that it became clear and directed qualitative descriptive information. The indentity of the respondent taken based on the type of work of the respondent. The age of the respondents in this study was not determined because in this study the respondents selected were not based on age but based on who the people were still doing shifting cultivation. Administratively, Sempurna Village is an area in the sub-district of Sungai Laur, Ketapang Regency with an area of $992(\mathrm{ha})$. The problem is faced by the people still doing shifting cultivation is that every year they find difficult to get land, so the people who use the protected forest of Gunung Palung National Park, the reason they dare to use protected forest areas as they cultivate because, more difficult to get land because those who are not protected forest area are now increasingly planted with oil palm plantations.
\end{abstract}

Keyword: Ketapang District, Palem Oil, Sempurna Villages, Shifting Cultivators, Sosial Problems

\section{PENDAHULUAN}

Masyarakat peladang berpindah adalah sekumpulan orang berocok tanam di ladang dengan menggunakan sekumpulan teknik untuk hidup yang dianut oleh orang-orang yang memandangnya sebagai prosedur praktis dalam rangka memenuhi kebutuhan hidupnya, masyarakat ini biasanya tinggal di wilayah perdesaan, yang komunitasnya terdiri dari 100 - 200 orang. Jarang berjumlah besar, kecuali orang Baduy di Jawa Barat, Garna (1988).

$$
\text { Penelitian Roslinda (2012), }
$$

mengatakan perladangan berpindah di Kalimantan Barat, terdapat beberapa 
Kabupaten yakni diantaranya Kapuas Hulu, Sanggau, Ketapang, Landak yang mendeskripsikan bahwa perladangan berpindah bagi masyarakat yang melakukan perladangan berpindah merupakan sistem bertani yang sudah di lakukan secara turun temurun oleh masyarakat peladang berpindah, masyarakat Desa Sempurna Kecamatan Sungai Laur Kabupaten Ketapang, saat ini masih melakukan kegiatan perladangan berpindah yang bertujuan untuk memenuhi kebutuhan hidupnya.

Masyarakat Desa Sempurna Kecamatan Sungai Laur Kabupaten Ketapang melakukan kegiatan ladang berpindah ini dengan tujuan yaitu untuk mendapatkan hasil tanaman ladang seperti padi, palawija yang dapat membantu pertumbuhan ekonomi masyarakat tersebut. Hal ini dapat diperkuat pada pendapat Lumangkum (1993), mengatakan perladangan berpindah sebagai salah satu cara manusia memanfaatkan alam dalam rangka memenuhi kebutuhan hidup.

Perkebunan kelapa sawit yang mulai beroperasi pada tahun 2002 di sekitar Desa Sempurna sedikit banyak menimbulkan dampak negatif terhadap masyarakat sekitar, salah satu dampak yang ditimbulkan ialahpermasalah sosial yang diakibatkan oleh berkurangnya lahan pertanian dari tahun ketahun bagi masyarakat setempat khususnya masyarakat yang menggantungkan hidupnya pada kegiatan pertanian perladangan berpindah untuk memenuhi kebutuhan sehari-hari mereka. Oleh sebab itu perlu dilakukannya penelitian tentang permasalahan sosial pada masyarakat ladang berpindah akibat perkebunan Kelapa sawit di Desa Sempurna Kecamatan Sungai Laur Kabupaten Ketapang, permasalahan sosial masyarakat peladang berpindah di desa sempurna ini dibatasi pada masalah berkurangnya lahan pertanian, pendapatan masyarakat peladang,perubahan mata pencarian masyarakat.

\section{METODE PENELITIAN}

Penelitian ini dilaksanakan di Desa Sempurna Kecamatan Sungai Laur Kabupaten Ketapang Kalimantan Barat. Penelitian ini menggunakan metode survei. Jenis penelitian yang dilakukan adalah penelitian kualitatif dengan lebih menitik beratkan pada gambaran yang lengkap tentang fenomena yang dikaji dengan lokasi penelitian. Adapun subjek penelitian sebagai sumber data primer adalah masyarakat peladang berpindah di Desa Sempurna Kecamatan Sungai Laur Kabupaten Ketapang. Teknik pengumpulan data melalui observasi, wawancara, dan dokumentasi, dengan alat bantu berupa pedoman wawancara atau kuesioner, catatan observasi, kamera, dan alat tulis menulis. Pengolahan data yang telah dikumpulkan melalui tahapan klasifikasi dan interprentasi data dan selanjutnya dilakukan pembahasan nberupa analisis data yang mencangkup penafsiran semua data yang telah dikumpulkan, melakukan pengaturan hasil-hasil penelitian sedemikian rupa sehingga menjadi informasi deskriptif kualitatif yang jelas dan terarah.

HASIL DAN PEMBAHASAN Identitas Responden 
Berdasarkan hasil penelitian yang dilakukan terhadap masyarakat Desa Sempurna yang masih melakukan perladangan berpindah hanya 12 orang yang saat ini masih tetap melakukan perladangan secara berpindah-pindah dengan umur rata-rata 50 tahun keatas dan tingkat pendidikan yang sangat rendah hanya sampai sekolah dasar (SD).

Masyarakat yang tidak lagi berladang untuk saat ini bekerja sehari-hari sebagai petani karet, berkebun, dan ada juga yang ikut menanam kelapa sawit, dan ada juga yang bekerja di perusahaan perkebunan kelapa sawit. Alasan mereka tidak berladang dikarenakan semakin luasnya perkebunan kelapa sawit sehingga lahan untuk berladangpun semakin sulit didapat.Semenjak adanya perkebunan kelapa sawit pola kehidupan masyarakat banyak berubah yang dulunya masyarakat selalu mengutamakan kebun karet sebagai mata pencarian utama sekarang kebun karet banyak di tebangi di ganti dengan kelapa sawit dengan alasan hasilnya lebih banyak dan jangka waktu panen yang relatif lebih cepat.

Secara administratif Desa Sempurna merupakan wilayah yang berada di Kecamatan Sungai Laur Kabupaten Ketapang dengan luas wilayah 30.383 (ha). Akses menuju Desa Sempurna dapat ditempuh melalui jalan darat dengan kendaraan roda dua, roda empat.

Guna memenuhi kebutuhan pokok sehari-hari masyarakat Desa Sempurna kebanyakan hanya bekerja sebagai petani, bertani sawah dan berladang secara berpindah-pindah jarak yang di tempuh untuk ke lokasi ladang mereka dapat di tempuh dengan kendaraan roda dua itu pun biasanya kendaraan mereka hanya bisa setengah jalan selebihnya mereka berjalan kaki tetapi kebanyakan mereka hanya bisa berjalan kaki untuk ke lokasi ladang mereka di karenakan keadaan jalan yang tidak mendukung karena lokasi perladangan mereka sangat jauh di dalam hutan jauh dari pemukiman desa tempat mereka tinggal sehari-hari.

Permasalahan Sosial Pada Masyarakat Ladang Berpindah Akibat Perkebunan Kelapa Sawit

Perkebunan kelapa sawit yang mulai beroperasi di Desa Sempurna pada tahun 2002 telah menimbulkan sisi positif dan negatinf. Sisi positif dengan adanya perkebunan kelapa sawit setidaknya dapat membantu perekonomian, membuka lapangan pekerjaan. Hasil wawancara di lapangan dengan masyarakat menyatakan bahwa masayarakat yang dulunya melakukan perladangan berpindah bekerja di perusahaan sampai saat ini terserap sebanyak 26 orang yang sebagian besar bekerja sebagai karyawan persemaian, pemiliharaan tanaman, pemanenan, mandor, menjadi sopir di perusahaan. Sedangkan dari segi negatif yang ditimbulkan ialah permasalahan sosisal yang diakibatkan oleh berkurangnya lahan pertanian dari tahun ketahun bagi masyarakat setempat khususnya masyarakat Desa Sempurna yang mengantungkan hidupnya pada kegiatan pertanian ladang berpindah untuk memmenuhi kebutuhan sehari-hari mereka.

Wawancara yang dilakukan peneliti terhadap masyarakat yaitu masyarakat yang melakukan perladangan secara 
berpindah-pindah permasalah sosial yang dihadapi masyarakat saat ini adalah.

1. Semakin sulitnya mendapatkan lahan untuk berladang karena lahan sudah dimiliki atau beralih kepada pihak perusahaan perkebunan kelapa sawit.

2. Masyarakat peladang pada saat ini melakukan perladangan dengan merambah dikawasan Taman Nasional Gunung Palung (TNGP) Karena Desa Sempurna berbatasan langsung dengan Taman Nasional Gunung Palung (TNGP) yang memiliki luas (25.331 ha) sebagaiman dapat di buktikan dengan obserpasi di lapangan bahwa perladangan sudah memasuki kawasan Taman Nasional Gunung Palung (TNGP).

3. Masyarakat yang masih melakukan perladangan berpindah ini adalah masyarakat yang tidak dapat ditampung sebagai tenaga kerja perusahaan. Hal ini dikarenakan masalah usia atau tingkat umur yang rata-rata 50 tahun keatas, dan memiliki tingkat pendidikan yang sangat rendah rata-rata tingkat pendidikan masayarakat hanya sampai sekolah dasar (SD). Dengan masuknya perkebunan kelapa sawit di Desa Sempurna tidak semua masyarakat dapat terserap menjadi tenaga kerja oleh sebab itu untuk mempertahankan hidup bagi masyarakat saat ini satusatunya hanya melakukan perladangan berpindah. sebagaimana di ketahui bahwa pertanian ladang berpindah ini sudah di kuasai oleh masayarakat, tidak membutuhkan keterampilan yang tinggi, dan biaya yang banyak. Dan dapat menghasilkan kebutuhan pokok seperti padi, dan tanaman palawija atau syur-sayuran.

Sesuai pendapat Koentjaraningrat (1977). Yang menyatakan bahwa Perladangan berpindah adalah sebuah sistem pertanian yang memiliki karakteristik teknis tebas, bakar, di lakukan di daerah tanah yang kering, tidak ada pengairan intensif dan di tanam dengan jenis tanaman yang berumur pendek. Pada umumnya setelah di garap tiga tahun atau kurang kemudian di tinggalkan. Tanamannya berjenis padi atau palawija dengan teknik pengolahan yang sederhana yaitu dengan menggunakan tugal, disertai dengan pemanfaaatan tanah dan pemeliharaan tanaman tanpa pemupukan.

4. Terjadinya permasalah sosial yang menyangkut lahan, berupa saling mengklaim kepemilikan lahan sehingga ada sebagian dari masyarakat tersebut yang mengambil hah-hak orang lain (merebut lahan) demi kepentingan pribadi.

5. Belum tersedianya lahan cadangan pangan bagi masyarakat desa yang berladang berpindah. Hal ini di karenakan pihak perusahaan sampai saat ini belum mengalokasikan dan merealisasikan kewajiban menyediakan lahan cadangan pangan bagi masyarakat desa. Dari segi negatif dengan adanya perkebunan kelapa sawit saat ini yang semakin luas,dengan adanya kebun kelapa sawit tersebut membuat mereka sulit untuk mendapatkan lahan untuk melakukan perladangan dengan cara berpindah yang dulunya mereka sangat mudah untuk mendapatkan lahan untuk 
berladang tetapi sekarang setelah adanya pekebunan kelapa sawit yang ada di Desa Sempurna Kecamatan Sungai Laur Kabupaten Ketapang mereka semakin sulit untuk mendapatkan lahan.

Sebagaiman di tegaskan dalam undang-undang perkebunan No 39 Tahun 2014 pada pasal 3 yang menyebutkan bahwa penyelengaraan perkrbunan bertujuan untuk:

1. Meningkatkan kesejahteraan dan kemakmuran masyarakat

2. Menyediakan lapangan kerja dan kesempatan usaha

3. Memberikan perlindungan kepada pelaku usaha perkrbunan dan masyarakat

4. Mengelola dan mengembangkan sumberdaya perkrbunan secara optimal, bertanggung jawab, dan lestari

Kehadiran perusahaan itu menurut hasil wawancara dari masyarakat menyebabkan masyarakat memiliki kebun kemitraan setiap kepala keluarga. hal ini sesuai dengan peraturan mentri pertanian No 98 tahun 2013 tentang Pedoman Perizinan Usaha Pertanian yang sebagaimana di jelaskan pada pasal 15 bahwa:

1. Perusahaan Perkebunan yang mengajukan IUP-B atau IUP dengan luas 250 (dua ratus lima puluh) hektar atau lebih, berkewajiban memfasilitasi pembangunan kebun masyarakat sekitar dengan luasan paling kurang $20 \%$ (dua puluh perseratus) dari luas area IIP-B atau IUP

2. Kebun masyarakat yang di fasilitasi pembangunannya sebagaimana dimaksud berada di luar area IUP-B atau IUP

3. Kewajiban memfasilitasi pembangunan kebun masyarakat sekitar sebagaimana dimaksud mempertimbangkan:

a. Ketersediaan lahan

b. Jumlah keluarga masyarakat sekitar yang layak sebagai peserta; dan

c. Kesepakatan antara Perusahaan Perkebunan dengan masyarakat sekitar dan diketahui kepala dinas provinsi atau kabupaten/kota yang membidangi perkrbunan sesuai kewenangannya

4. Masyarakat sekitar yang layak sebagai peserta sebagaimana dimaksud

a. Masyarakat yang lahannya digunakan untuk pengembangan perkebunan dan berpenghasilan rendah sesuai peraturan perundang-undangan

b. Harus bertempat tinggal di sekitar lokasi IUP-B atau IUP; dan

c. Sanggup melakukan pengelolaan kebun

5. Kewajiban memfasilitasi pembangunan kebun masyarakat sekitar sebagaimana dimaksud dilakukan dengan memanfaatkan kredit, bagi hasil dan/atau bentuk pendanaan lain sesuai dengan kesepakatan dan peraturan perundang-undangan.

Sampai saat ini masyarakat peladang berpindah yang menyerahkan lahan telah mendapatkan pembagian kebun kemitraan sebanyak 255 KK. Di mana setiap kepala keluarga telah memperoleh seluas 2 hektar (ha) kebun sawit atau 1 kapling. Masyarakat yang dulunya melakukan 
perladangan berpindah saat ini mendapat penghasilan dari kebun kemitraan.

Berdasarkan peraturan daerah Kabupaten Ketapang No 7 Tahun 2015 tanggal 29 Desember 2015 tentang perijinan dan pembinaan usaha perkebunan serta pola kemitraan, sebagai mana di jlaskan pada pasal 42 perusahaan perkebunan yang telah memiliki IUP-B, IUP,P atau IUP sesuai peraturan ini wajib:

1. Memiliki sumberdaya manusia, sarana prasarana dan sistem pembukaan lahan tanpa bakar serta pengendalian kebakaran

2. Menerapkan teknologi pembukaan lahan tanpa bakar dan mengelola sumber daya alam secara lestari

3. Memfasilitasi pembanguan kebun masyarakat bersamaan dengan pembangunan kebun perusahaan dan pembangunan kebun masyarakat

4. Melakukan kemitraan dengan pekebun, karyawan dan masyarakat sekitar

\section{Perubahan Sosial Dengan Adanya Keberadaan Perkebunan Kelapa Sawit}

Adanya perusahaan perkebunan kelapa sawit di Desa Sempurna telah menyebabkan terjadinya perubahan sosial bagi masyarakat ladang berpindah dari masyarakat yang melakukan pertanian perladangan berpindah menjadi masyarakat pekerja atau karyawan perusahaan. Sebagaiman di jelaskan oleh William F. Ogburn dalam Moore (2002). Perubahan sosial adalah segala perubahan yanag terjadi dalam lembaga kemasyarakatan dalam suatu masyarakat, yang mempengaruhi sistem sosialnya. Tekanan pada definisi tersebut adalah pada lembaga masyarakat sebagai himpunan kelompok manusia dimana perubahan mempengaruhi struktur masyarakat lainya. Faktor- faktor yang dapat mempengaruhinya antara lain:

1. Bertambah atau berkurangnya penduduk

Pertambahan penduduk yang cepat akan menyebabkan perubahan dalam struktur masyarakat khususnya dalam lembaga kemasyarakatan sedangkan berkurangnya penduduk akan berakibat terjadinya kekosongan baik dalam pembagian kerja, maupun statifikasi sosial.

2. Penemuan-penemuan baru

Suatu peroses sosial dan kebudayaan yang besar, tetapi terjadi dalam jangka waktu yang tidak terlalu lama, adalah inovasi. Proses tersebut meliputi suatu penemuan baru, jelasnya unsur kebudayaan baru yang tersebar ke lain-lain bagian masyarakat dan cara-cara unsur kebudayaan baru diterima, dipelajari dan akhirnya dipakai dalam masyarakat yang bersangkutan. Penemuan baru sebagai akibat terjadinya perubahan-perubahan dapat dibedakan dalam pengertian discovery dan invention. Discovery adalah penemuan unsur kebudayaan yang baru baik berupa alat, ataupun yang berupa gagasan yang diciptakan oleh seorang individu atau serangkaian ciptaan individu para individu. Discovery akan menjadi invention, jika masyarakat sudah mengakui, serta menerapkan penemuan baru tersebut.

3. Pertentangan (komplik) masyarakat

Pertentangan ini bisa terjadi antara individu dengan kelompok ataupun antar kelompok dengan kelompok, misalnya pertentangan atar generasi. 
Perubahan sosial merupakan perubahan kehidupan masyarakat yang berlangsung terus-menerus dan tidak akan pernah berhenti, karena tidak ada satu masyarakatpun yang berhenti pada suatu titik tertentu sepanjang masa. Artinya, meskipun para Sosiolog memberikan klasifikasi terhadap masyarakat statis dan dinamis, namun yang dimaksud masyarakat statis adalah masyarakat yang sedikit sekali mengalami perubahan dan berjalan lambat, artinya di dalam masyarakat statis tersebut tetap mengalami perubahan. Adapun masyarakat dinamis adalah masyarakat yang mengalami berbagai perubahan yang cepat.

Manusia memiliki peran sangat penting terhadap terjadinya perubahan masyarakat. Perubahan itu terjadi sesuai dengan hakikat dan sifat dasar manusia yang selalu ingin melakukan perubahan, karena manusia memiliki sifat selalu tidak puas terhadap apa yang telah dicapainya, ingin mencari sesuatu yang baru untuk mengubah keadaan agar menjadi lebih baik sesuai dengan kebutuhannya.

Salah satu indikator keberhasilan adanya kebun kelapa sawit adalah dengan terbentuknya lapangan pekerjaan bagi masyarakat lokal atau masyarakat pendatang dan petumbuhan ekonomi maka dari itu taraf hidup masyarakat juga semakin meningkat. Perubahan yang terjadi di masyarakat mencagkup pula perubahan pada pola pemanfaatan lahan yang ada untuk kegiatan pertanian. Pada lahan-lahan bekas perladangan yang sudah di tinggalkan, dulunya terlebih dahulu ditanami dengan ubi kayu, baru kemudian setelah masa-masa beberapa lama ditanami dengan tanaman buah-buahan dan karet sebagai tanaman perkebunan berumu relatif panjang. Saat ini pemanfaatan lahan bekas ladang selaian ditanami dengan pohon karet, ditanamai pula dengan pohon sawit yang relatif cepat.

\section{Alasan Utama Masyarakat Melakukan Perladangan Berpindah}

Hasil wawancara dilapangan yang telah dilakukan terhadap 12 responden alasan masyarakat saat ini masih melakukan perladangan berpindah kerena untuk memenuhi kebutuhan hidup mereka sehari-hari. Selain untuk memenuhi kebutuhan hidup sehari-hari berladang berpindah juga sudah menjadi tradisi atau sudah menjadi budaya. Sejalan dengan penelitian Lubis (1997), secara garis besar di temukan paling sedikit ada empat faktor yang mendasari keputusan petani dalam pengelolaan lahan hutan adalah sebagai berikut:

1. Faktor kultural

Pengaruh kultural mencangkup pengetahuan, kepercayaan dan nilainilai budaya yang terkait dalam pengelolaan lahan hutan. Seperti suku dayak di Kalimantan, berladang bukan sekedar untuk hidup tetapi ladang turut membentuk peradaban orang Dayak, karena dari membuka lahan hingga akhir panen ada aturan yang harus di taati adatnya inilah yang membentuk kebudayaan Dayak.

2. Faktor ekonomis

Pengaruh ekonomis mencakup pariabelpariabel ekonomi, seperti fluktuasi harga, akses pasar, modal (material, tenaga kerja dan waktu), dan kebutuhan ekonomi rumah tangga. 
Tetapi pada sistem perladangan berpindah, modal yang di butuhkan hanya untuk biaya konsumsi bagi meraka yang terlibat dalam membantu pekerjaan. Namun demikian ada juga peladang yang memiliki kemampuan untuk bekerja tanpa bantuan, sehingga tidak membutuhkan biaya.

\section{Faktor ekologis}

Pengaruh ekologis meliputi kualitas tanah, topografi lahan, dan perilaku tanaman. Seperti masyarakat dayak di Kalimantan umumnya melakukan sistem ladang berpindah untuk mengelola hutan karena tanah Kalimantan miskin mineral, di mana fosfor menjadi pembatas bagi budi daya tanaman pangan. Di hutan tropis, fosfor tersimpan dalam pohon sehingga perlu pembakaran hutan untuk melepaskannya.

\section{Faktor sosial}

Pengaruh sosial meliputi setatus sosial dan hubungan-hubungan sosial. Terbatasnya pengetahuan dari peladang, mayoritas peladang khususnya di Indonesia berpendidikan SD dan SMP namun demikian terdapat juga yang berpendidikan SMA, terutama bagi mereka yang sulit untuk mendapatkan pekerjaan di kota. Berdasarkan pantauan lapangan menunjukan bahwa teknik pembersihan ladang hanya dengan cara membakar, kemudian tidak melakukan pengolahan tanah untuk penanaman dan tidak menguasai teknik seleksi bibit yang baik agar produksi dapat meningkat.

Pengaruh kultural mencangkup pengetahuan, kepercayaan dan nilai-nilai budaya yang terkait dalam pengelolaan lahan hutan. Seperti suku dayak di Kalimantan, berladang bukan sekedar untuk hidup tetapi ladang turut membentuk peradaban orang Dayak, karena dari membuka lahan hingga akhir panen ada aturan yang harus di taati adatnya inilah yang membentuk kebudayaan Dayak.

Selain menanam padi mereka juga menanam tanaman yang lainya juga seperti sayur-sayuran dan yang lainnya.Pada saat ini untuk beralih profesi pekerjaan sangat sulit dikarenakan masyarakat di tuntut untuk memiliki pendidikan yang lebih tinggi sedangkan kebanyakan dari mereka hanya berpendidikan paling tinggi pada tingkatan SMP,itu pun hanya sebagian dari mereka kebanyakanya hanya berpendidikan SD.

Selanjutnya dijelaskan oleh Lubis (1997). Pada sistem perladangan berpindah, modal yang di butuhkan hanya untuk biaya konsumsi bagi meraka yang terlibat dalam membantu pekerjaan. Namun demikian ada juga peladang yang memiliki kemampuan untuk bekerja tanpa bantuan, sehingga tidak membutuhkan biaya. Ini lah yang merupakan alasan masyarakat masih melakukan kegiatan perladangan berpindah.

\section{KESIMPULAN}

Masalah yang di hadapai masyarakat masih melakukan perladangan berpindah saat ini adalah setiap tahunnya mereka semakin sulit mendapatkan lahan sehingga masyarakat ada yang menafaatkan kawasan hutan lindung yaitu Taman Nasional Gunung Palung (TNGP). Yang ada di Desa Sempurna Sebagai tempat mereka berladang. 


\section{SARAN}

Di harapkan kepada masyarakat (petani) dapat mengontrol kegiatan di dalam kawasan Taman Nasional Gunung Palung (TNGP), agar tetap lestari, maka pemerintah melalui lembaga terkait perlu pembinaan kepada masyarakat agar tidak melakukan perladangan berpindah di sekitar kawasan hutan Taman Nasional Gunung Palung. Dan di harapkan adanya kerjasama dari instansi terkait, elemen masyarakat pihah perusahan untuk mencari solisi mengatasi pengarapan lahan pertanian yang dijadikan lahan perkebunan melalui kebijakan-kebijakan pemerintah

\section{UCAPAN TERIMAKSIH}

Penulis mengucapkan terimakasih kepada; Bapak Ir. Iskandar AM, M.Si selaku Dosen Pembimbing Pertama dan Bapak Ir. H.M. Idham, M.Si selaku Dosen Pembimbing Kedua.

\section{Daftat Pustaka}

B. Ioom W illiam, Don W. Faw catt. 2002. Buku ajar histologi. Jakatra.

Garna. Judistira K. 1988. Tangtu Telu Jaro Tujuh, Kajian Struktural Masyarakat Baduy diBanten
Selatan, Jawa Barat Indonesia, Disertasi, Fakulti Sains Kemasyarakatan dan Kemanusian Universiti Kebangsaan Malaysia.

Koentjaraningrat, 1977. Beberapa Pokok - Pokok Antropologi, Jakarta: Dian Rakyat.

Lumangkum, Agustine. 1993. Ladang Berpindah Kegiatan Yang Sering Dipermasalahkan, Dalam: Suara Almamater Universitas Tanjungpura Nomor 6 Tahun $\mathrm{X}$, April

Lubis, z. 1997. Repong Damar; Kajian Tentang Pengambilan Keputusan Dalam Pengelolaan Lahan Hutan di Pesisir Krui. Lampung Barat.

Roslinda, E. (2012). Persepsi Masyarakat Terhadap Kegiatan Agroforestri: Perladangan Berpindah. Seminar Nasional Agroforestri III

Shadily, Hasan. 1993. Sosiologi untuk Masyarakat Indonesia. Jakarta: PT. RinekaCipta.

Undang- Undang Republik Indonesia. 2014. Tentang Perkebunan. Jakarta. 